\title{
A Class IV Chitinase Is Up-Regulated by Fungal Infection and Abiotic Stresses and Associated with Slow-Canker-Growth Resistance to Cronartium ribicola in Western White Pine (Pinus monticola)
}

\author{
Jun-Jun Liu, Abul K. M. Ekramoddoullah, and Arezoo Zamani
}

Pacific Forestry Centre, Canada Forest Service, Natural Resources Canada, Victoria, British Columbia, V8Z 1M5, Canada. Accepted for publication 16 November 2004.

\begin{abstract}
Liu, J.-J., Ekramoddoullah, A. K. M., and Zamani, A. 2005. A class IV chitinase is up-regulated by fungal infection and abiotic stresses and associated with slow-canker-growth resistance to Cronartium ribicola in western white pine (Pinus monticola). Phytopathology 95:284-291.

In the present study, in a candidate gene approach, a class IV chitinase gene $(P m C h 4 A)$ of pathogenesis-related family three was cloned and characterized in western white pine (Pinus monticola). $\mathrm{PmCh} 4 \mathrm{~A}$ chitinase expression in the different organs of healthy seedlings was below levels detectable by western immunoblot analysis using an antibody raised against PmCh4A protein. However, a 27-kDa isozyme of PmCh4A accu-

mulated in both susceptible and slow-canker-growth (SCG) resistant seedlings after infection by Cronartium ribicola. As with fungal infection, the application of a signal chemical (methyl jasmonate) and a protein phosphatase 1 and 2A inhibitor (okadaic acid) increased the PmCh4A protein accumulation. Furthermore, another $26-\mathrm{kDa}$ isozyme was expressed specifically in SCG resistant seedlings, providing a potential tool for marker-assisted selection in forest breeding. Wounding treatment also induced expression of the protein. These data suggest that the class IV chitinase PmCh4A is involved in the defense response of western white pine to infection and abiotic stresses.
\end{abstract}

Western white pine (WWP; Pinus monticola Dougl. Ex D. Don) is a fast-growing species that reduces rotation period and increases quantity of wood in second-growth forests. This conifer has excellent genetic resistance to root rot caused by Inonotus tomentosus, Armillaria spp., and Phellinus weirii. However, it is rarely planted because of an epidemic of white pine blister rust caused by the fungus Cronartium ribicola (J.C. Fisch) which was introduced to North America around 1910. This rust is an ecologically and economically significant disease and has resulted in reduced planting of WWP and other five-needle pines (28).

Because almost all North American WWP is susceptible to C. ribicola, it is important both to obtain genetic resistance to C. ribicola and to maintain genetic diversity among populations used in WWP breeding programs. Genetic resistance to white pine blister rust varies widely among WWP populations. Several types of WWP genetic resistance to white pine blister rust, including slow-canker-growth (SCG) (18) and major dominant gene resistance $(\mathrm{Cr} 2)(21)$, have been identified after multiyear genetic breeding studies. SCG resistance is a durable resistance that is expressed in WWP seedling stems; it restricts the infection area, and cankers eventually heal (18). Different kinds of SCG resistance have been observed, suggesting that it might be controlled by multiple genes $(12,25)$. At present, the selection of SCG resistance is a long-term task, requiring at least 6 to 7 years for the SCG phenotype to be fully expressed. A WWP breeding program requires increased understanding of the plant's defense mechanisms against $C$. ribicola, as well as a search for potential molecular markers for marker-assisted selection.

Chitinases are hydrolytic enzymes (EC 3.2.1.14) that catalyze the hydrolysis of chitin, a polymer of $N$-acetyl-D-glucosamine.

Corresponding author: A. K. M. Ekramoddoullah

E-mail address: aekramoddoul@nrcan.gc.ca

DOI: $10.1094 /$ PHYTO-95-0284

C 2005 Her Majesty the Queen in right of Canada, Natural Resources Canada, Canadian Forest Service
Chitin is a major component of cell walls of all true fungi, but is absent from plant cells. More than 100 chitinase genes and proteins have been identified in diverse plants. In the classification system of glycosyl hydrolases, chitinases belong to families 18 and 19 , based on the similarity of the catalytic domain sequences. Within these two families, chitinases are further grouped into seven classes according to their structures, enzymatic properties, and subcellular localizations. Class I, II, IV, VI, and VII chitinases make up family 19, whereas class III and V chitinases constitute family 18 (32). Under normal conditions, chitinases are expressed at low levels in certain organs at specific developmental stages, suggesting that some of them play a role in plant development (35).

Many chitinases are up-regulated by abiotic and biotic stimuli, such as fungal, bacterial, viral, and pest attacks. Chitinases are therefore also classified under the pathogenesis-related (PR) protein families PR3, PR4, PR8, and PR11, respectively $(32,43)$. The important roles that chitinases play in plant defense systems have been supported by their pathogen-induced gene expression patterns $(16,27,32,39,47)$, in vitro antifungal activity $(1,30,31,42)$, and enhanced transgene resistance against pathogens $(2,4,16$, $20,32,45,48)$. However, in other studies no effect on fungal resistance has been found when chitinase levels were up-regulated or down-regulated in transgenic plants $(16,32,33,41)$. More research is needed to elucidate how chitinases function in plant defense mechanisms.

Although the pathogen $C$. ribicola causes severe damage on five-needle pines, the mechanisms of pathogenicity and host defense response are poorly understood. In recent years, we have applied a proteomic strategy to investigate plant defense mechanisms in conifer pathosystems during fungal infection (12). Protein profiles from two-dimensional gels have been compared to search for differentially expressed proteins from susceptible and resistant conifers during pathogen infection $(6,14)$. We have focused on the role that PR proteins may play in the host defense response. Proteins of PR3 (6), PR5 (36), and PR10 (11,26) and an 
antifungal peptide $(6,13)$ have been found to be up-regulated by fungal infection in WWP.

To explore the possible involvement of chitinases in the defense response of conifers, an expressed sequence tag encoding a class IV chitinase gene $(\mathrm{PmCh} 4 \mathrm{~A})$ was isolated from WWP needles infected by $C$. ribicola. The cDNA cloning, genomic organization, and expression in response to fungal infection and abiotic stimuli are described here for $P m C h 4 A$.

\section{MATERIALS AND METHODS}

Plant materials and experimental treatments. Bark, twig, foliage, and root tissues were collected from fungus-infected seedlings and from uninfected, healthy WWP seedlings (Pinus monticola). To infect seedlings with $C$. ribicola, 2 -year-old seedlings from seed lots $3093,3110,3115$, and 3117 were inoculated in a Ribes (disease) garden with a composite inoculum from six coastal British Columbia sources of C. ribicola in August 1992. Seedlings were placed beneath $C$. ribicola-infected Ribes plants for 1 month while basidiospores were being released. The seedlings were grown outdoors under natural day length and temperature conditions at Cowichan Lake Research Station, Vancouver Island. Following infection, seedlings showing either of two phenotypes were selected for this study: susceptible seedlings that express cankers on stems, which eventually kill the seedlings; SCG seedlings that express limited cankers on stems, which eventually heal, and the seedlings survive. Bark, twig, and foliage samples were collected individually from nine infected seedlings for each phenotype in July 1995 for protein extraction. WWP seedlings used in all other experiments were grown in styrofoam blocks in shade houses or growth chambers at the Pacific Forestry Centre, Victoria, British Columbia, Canada.

The seedlings that were treated with methyl jasmonate (MeJ), okadaic acid (OA), and wounding were grown from a single seed lot in July and August 2000 and 2001 as described previously (26). Briefly, for wounding treatments, the needles were crushed at intervals of 3 to $4 \mathrm{~mm}$ with fine forceps and held in petri dishes for incubation. For chemical treatments, the needles were put into test solutions without chemicals (control) or into solutions with chemicals and transferred to petri dishes. Each dish had $3 \mathrm{MM}$ Whatman paper dampened with $1 \mu \mathrm{M}$ MeJ or $1 \mu \mathrm{M}$ OA. Each treatment was repeated three times. Each time tissue samples were taken from three individual seedlings, frozen in liquid nitrogen, and stored at $-80^{\circ} \mathrm{C}$ until analyzed.

Cloning of PmCh4A chitinase gene. To clone chitinase cDNA, the first-strand cDNA was synthesized with a template of total RNA extracted from infected needles of resistant seedlings using a SMART cDNA Library Construction Kit (Clontech Laboratories, Palo Alto, CA) and following the manufacturer's instructions. A reverse transcription-polymerase chain reaction (RTPCR) strategy was used for cDNA cloning of the chitinase gene. A reverse primer Ch3 (5'-ATT CTT CAT CCA GAA CCA-3') was designed at a highly conserved motif (WFWMKN) in the catalytic domain of the chitinase family. PCR was carried out with primer $\mathrm{Ch} 3$ and the Clontech PCR $5^{\prime}$ primer to amplify the $5^{\prime}$ end of the chitinase gene, including the $5^{\prime}$-untranslated region $\left(5^{\prime}\right.$ UTR) and the N-terminal coding region. Sequence analysis showed that the DNA fragment was a partial sequence of a class IV chitinase gene. Then, a gene-specific forward primer, Ch4A-5 (5'-GAA TCA ACA CAT CAA ATA ATC AGT TTG-3') within 5'UTR, was designed and synthesized. PCR was performed using the primer pair Ch4A-5/oligo(dT)30 to amplify the full-length PmCh4A cDNA from its 5'-UTR to the poly A tail. Full-length genomic clones were subsequently isolated by PCR with a genomic DNA template pooled from 10 disease-resistant seedlings using the forward primer Ch4A-5 and a reverse primer based on the $3^{\prime}$ UTR of the PmCh4A cDNA, Ch4A-3: 5'-GCC ATG GAC ATC AAT GAT AAT TG-3'.
PCR was carried out with a PCR Master Mix Kit (Qiagen Inc., Mississauga, Canada) using first-strand cDNA as the template. PCR thermal cycling conditions with primer pairs Clontech PCR $5^{\prime}$ primer/Ch3 consisted of an initial denaturation step at $94^{\circ} \mathrm{C}$ for 1 min followed by 35 cycles of denaturation at $94^{\circ} \mathrm{C}$ for $30 \mathrm{~s}$, annealing at $45^{\circ} \mathrm{C}$ for $1 \mathrm{~min}$, and extension at $72^{\circ} \mathrm{C}$ for $2 \mathrm{~min}$, with a final 10 -min extension at $72^{\circ} \mathrm{C}$. For the PCR with primer pairs Ch4A-5/oligo(dT) $)_{30}$ or Ch4A-5/Ch4A-3, amplification conditions were the same as above except that the primer annealing and extension steps were combined at $68^{\circ} \mathrm{C}$ for $3 \mathrm{~min}$. After agarose gel fractionation, the amplified DNA fragments with the expected sizes were purified and cloned into the pGEM-T easy vector (Promega, Madison, WI) according to the manufacturer's instructions.

DNA sequencing and computer analysis. DNA sequences of a few cDNA or genomic DNA clones were determined on both strands at the DNA Sequencing Facility at the Centre for Biomedical Research, University of Victoria, BC, Canada. DNA sequence data were assembled and analyzed using BLAST, Clustal W, and open reading frame finder network services at the National Center for Biotechnology Information (NCBI). A phylogenetic tree based on the amino acid sequence alignment was constructed (22). The reliability of the tree was established by conducting 1,000 neighbor-joining bootstrap sampling steps. All of the cDNA clones were identical. However, the genomic clones represented two distinct sequences from 10 independent recombinant clones. PmCh4A sequences of one cDNA and two genomic clones are deposited as GenBank accession nos. AY500842 to AY500844.

DNA blot analysis. For DNA blot analysis, genomic DNA was isolated from young needles of resistant seedlings with the Plant DNeasy Kit (Qiagen). After digestion with appropriate restriction endonucleases, genomic DNA fragments $(20 \mu \mathrm{g}$ per lane) were separated by electrophoresis in $0.8 \%$ agarose gel and blotted onto a nylon membrane. The PmChi4A cDNA probe was labeled with digoxigenin using a random primer labeling kit (Roche Applied Science, Laval QC, Canada). Hybridization and washing conditions were the same as those for RNA blot analysis described previously (24).

Production of specific anti-chitinase antibody and western immunoblot analysis. An antigenic region (CASGKSYHGRGPLQLS) within the protein deduced from the PmCh4A cDNA sequence was identified by the DNASTAR Program (DNASTAR Inc., Madison, WI). The synthesis of this antigenic peptide and production of a polyclonal antibody were carried out under a contract with MPS (Multiple Peptide Systems, San Diego, CA). Five milligrams of purified peptide was coupled through the terminal cysteine thiol to a carrier protein, keyhole limpet hemocyanin (KLH). The peptide-KLH was emulsified by mixing with Freund's complete adjuvant, and injected into five or six subcutaneous dorsal sites, for a total volume of $0.6 \mathrm{ml}(0.5 \mathrm{mg}$ of peptide and $1.0 \mathrm{mg}$ of conjugate) per immunization. Rabbits were repeatedly injected (over 2 months) with immunogen under a proprietary immunization schedule. Immunoaffinity gel was prepared with the synthetic peptide and antibody purification was carried out using affinity chromatography. Purity and specificity of the purified antibody were checked by sodium dodecyl sulfatepolyacrylamide gel electrophoresis (SDS-PAGE) and by enzymelinked immunosorbent assay (ELISA).

Total protein extraction, SDS-PAGE, and immunological detection of protein blots were carried out as described previously (11). The scanning, detection, and quantification of the blots were performed with Bio-Rad's Quantity One Software (version 4.0) (Bio-Rad, Mississauga, Canada) according to the instruction manual. The protein level detected by western immunoblot analysis was calculated based on the optical density (OD) of all pixels within the band boundary and expressed in OD units $x$ millimeter. 


\section{RESULTS}

Isolation and nucleotide sequence of a class IV chitinase gene. PCR using the $\mathrm{Ch} 3$ primer and the Clontech PCR 5' primer produced a DNA fragment about 700 bp long. A BLAST search revealed that the nucleotide sequence showed significant similarity with class IV chitinase genes of the PR3 family found in other species. Its full-length coding region, plus its $3^{\prime}$-UTR, was cloned with RT-PCR using the gene-specific primer Ch4A-5 and the oligo(dT)30 primer. The isolated WWP chitinase cDNA was designated $P m C h 4 A$.

The PmCh4A cDNA is 1,104 nucleotides in length and contains a putative poly (A) signal $5^{\prime}$-AATAAA-3' in the $3^{\prime}$-UTR. $P m C h 4 A$ has an open reading frame of 822 nucleotides that encodes a polypeptide of 273 amino acids. The presence of two inframe stop codons in the 5'-UTR of PmCh4A indicates that the complete reading frame was obtained. Comparative analysis of the deduced amino acid sequence with other chitinases reveals that $\mathrm{PmCh} 4 \mathrm{~A}$, from $\mathrm{N}$ - to $\mathrm{C}$-terminal end, consists of a signal peptide, a cysteine-rich chitin-binding domain, a glycine-rich hinge domain, and a catalytic domain (Fig. 1). The sequence of the first 25 amino acids at the N-terminal end is typical of signal peptides with a highly hydrophobic core and a typical amino acid composition near the cleavage site (Fig. 1) (46). PmCh4A chitinase does not contain a C-terminal extension signal sequence, which is necessary for vacuolar targeting of mature proteins, suggesting an extracellular location. The PmCh4A mature protein has a predicted molecular mass of $25 \mathrm{kDa}$ and an isoelectric point of 8.31. A chitin-binding domain signature PS00026 (2), C-x(4,5)-CC-S-x(2)-G-x-c-g-x(4)-[FYW]-C, is localized downstream of the signal peptide from positions Cys-30 to Cys-49 (Fig. 1). A conserved motif (NYNYG), essential to hydrolytic activity (44), is found in the catalytic domain at position Asn-177 to Gly-181. The structural features of PmCh4A suggest that it may have substrate and enzyme activity similar to those of other chitinases. A potential N-linked glycosylation site $(\mathrm{N}-\mathrm{X}-\mathrm{S} / \mathrm{T})$ is present at the $\mathrm{C}$ terminal region. Compared with class I chitinases, class IV chitinases have four deletions: one in the chitin-binding domain and three in the catalytic domain. These characteristic deletions are also identified in the $\mathrm{PmCh} 4 \mathrm{~A}$ protein, indicating that it belongs to class IV chitinases of the PR3 family.

The amino acid sequence alignment showed that PmCh4A chitinase had different identities with class IV chitinases reported in other species, including Pgchi (85\%) from Picea glauca (10), Vvchi4A (60\%) and Vvchi4B (59\%) from grape berry (Vitis vinifera) (38), BvSP2 (50\%) from sugar beet (Beta vulgaris) (34), AtchitIV (50\%) from Arabidopsis thaliana $(8,35)$, and P4ch (49\%) from common bean (Phaseolus vulgaris) (29). A phylogenetic tree was constructed based on the deduced protein sequences of class IV chitinases of the PR3 family found in GenBank (Fig. 2). PmCh4A was most closely clustered with a class IV chitinase member from Picea glauca (Pgchi) and distantly related to other class IV chitinases from angiosperms, including representative species of dicots ( $A$. thaliana and Phaseolus vulgaris) and monocots (Oryza sativa and Zea mays). This suggests rapid adaptive evolution may have occurred in class IV chitinases after the divergence of gymnosperms and angiosperms (3).

Genomic organization. To determine the genomic organization of PmCh4A, genomic DNA of SCG seedlings was amplified

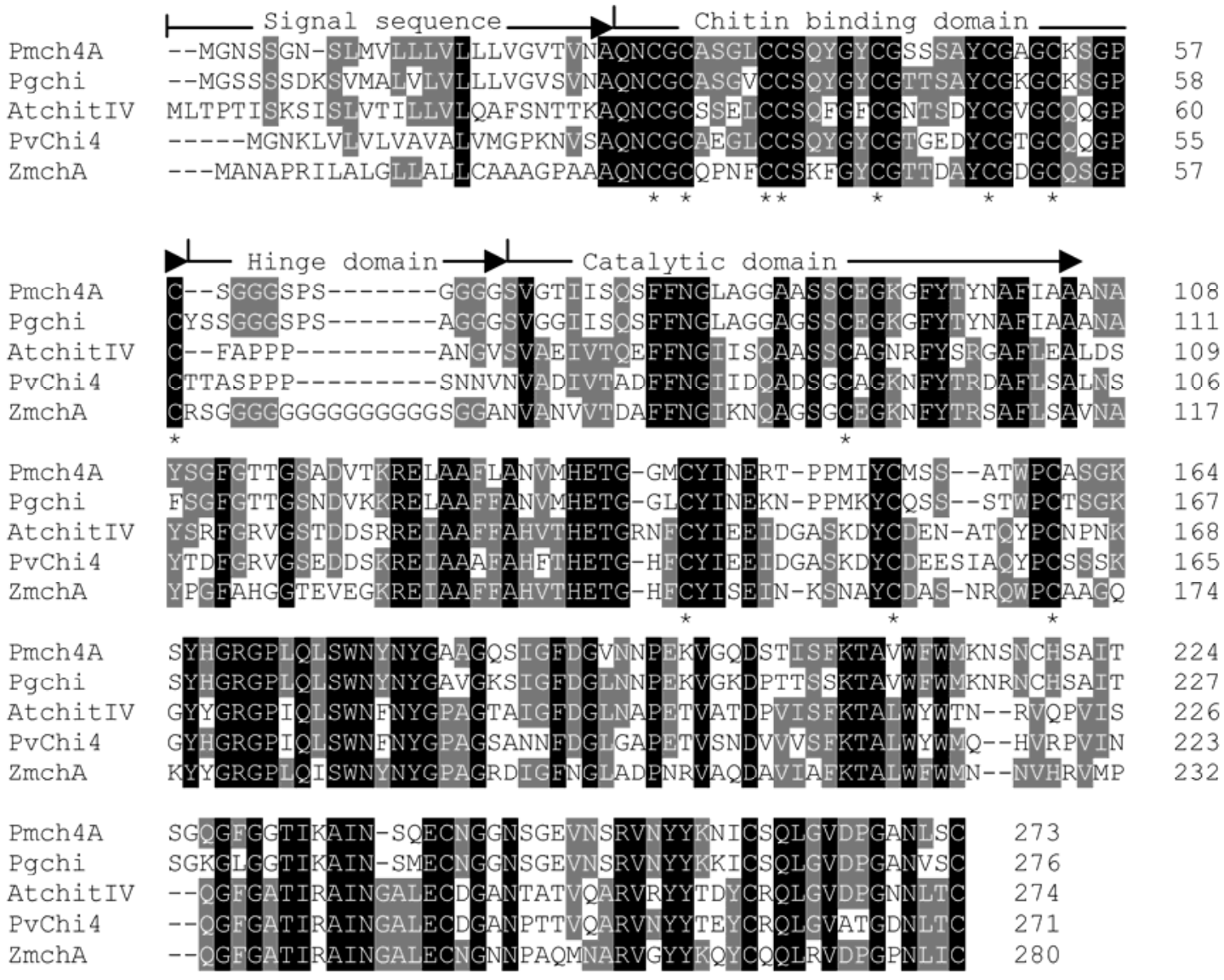

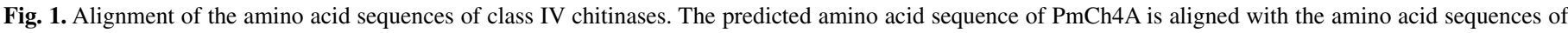

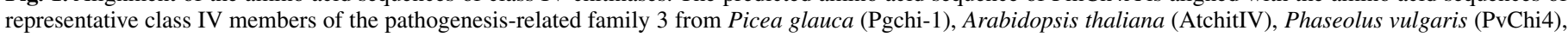

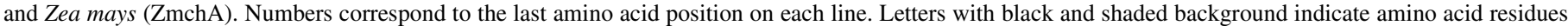

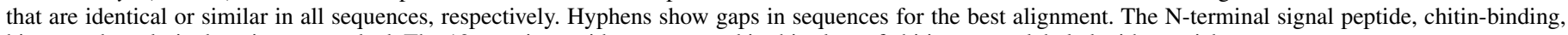
hinge, and catalytic domains are marked. The 12 cysteine residues conserved in this class of chitinases are labeled with asterisks. 
by PCR with the gene-specific primers Ch4A-5 and Ch4A-3. Sequence analysis of PCR fragments revealed genomic DNA polymorphism of the WWP class IV chitinase gene. The genomic clone PmCh4Aa is almost identical to the cDNA clone PmCh4A except for four nucleotides, two in the coding region and two in the $3^{\prime}$-UTR. Only one of the nucleotide substitutions results in an amino acid change $\left(R_{123}\right.$ to $\left.G_{123}\right)$. Except for intron regions, genomic clone $P m C h 4 A b$ has $98 \%$ identity with cDNA clone $\mathrm{PmCh} 4 \mathrm{~A}$ at the nucleotide level and $96 \%$ at the deduced amino acid level. The putative mature proteins encoded by PmCh4Aa and $P m C h 4 A b$ have the same $\mathrm{pI}$ and slightly different molecular masses (25.3 and $25.7 \mathrm{kDa}$, respectively), so they may not be separable on a protein gel. Interestingly, the primers Ch4A-5 and Ch4A-3 failed to amplify fragments from genomic DNA pooled from 10 susceptible seedlings. But a pair of primers targeted at internal regions of the conserved amino acid sequence amplified predicted DNA fragments of class IV chitinase from the genomic DNA of the susceptible seedlings. Although the exon sequences of these class IV chitinase gene fragments from susceptible seedlings were highly identical to the corresponding cDNA regions of $\mathrm{PmCH} 4 \mathrm{~A}$, their intron sequences had no obvious homology with those of PmCH4Aa or PmCh4Ab (data not shown). These data suggest that the sequence of class IV chitinase genes in SCG seedlings is different from that in susceptible seedlings.

Both PmCh4Aa and PmCh4Ab contain two introns of 311 and $90 \mathrm{bp}$, respectively. These two introns are AT rich (69\%) and possess a consensus splice junction of $5^{\prime}-\mathrm{GT}$ and $3^{\prime}$-AG. The two introns share 95 and $98 \%$ identities between PmCh4Aa and $P m C h 4 A b$, suggesting that these two genomic clones probably represent alternate alleles of the PmCh4A locus. The presence of two introns is unique in class IV chitinase genes, because only one intron has been identified in angiosperm class IV chitinase genes. The position of the first PmCh4A intron is identical to that of the sole intron of angiosperm class IV chitinase genes, such as A. thaliana AtchitIV (8) and Phaseolus vulgaris P4-ch (29). The positions of both $P m C h 4 A$ introns are the same as those of the two introns found in most angiosperm class I and II chitinase genes, which suggests a common ancestry for the PR3 family during plant evolution.

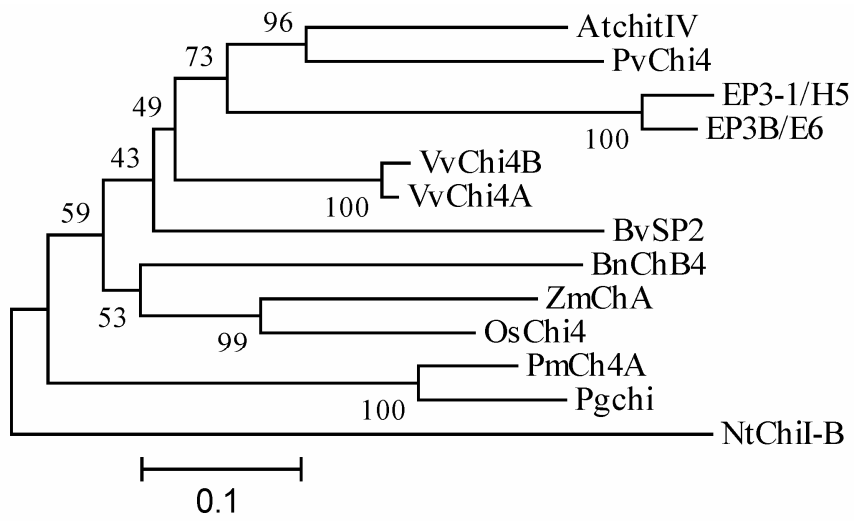

Fig. 2. Phylogenetic tree of amino acid sequences of PmCh4A and class IV chitinases from other species. This phylogenetic tree was constructed based on the comparison of PmCh4A amino acid sequence with other class IV chitinase sequences using the software Clustal W. The class IV chitinases analyzed here include EP3B/E6 and EP3-1/H5 from carrot (U52845 and U52848), OsChi4 from Oryza sativa (CAD41543), ZmchA from Zea mays (A42424), VvChi-4A and VvChi-4B from Vitis vinifera berry (U97521 and U97522), AtchitIV from Arabidopsis thaliana (Y14590), PvChi4 from Phaseolus vulgaris (X57187), BvSP2 from Beta vulgaris (L25826), BnCh4B from Brassica napus (X61488), and Pgchi from Picea glauca (L42467). A class I chitinase NtChiI-B from Nicotiana tabacum (X64519) is used as an outgroup in this tree. The scale at the lower part of the figure indicates genetic distance proportional to the substitutions per site.
In order to investigate the organization of this chitinase gene in the WWP genome, genomic DNA was digested with restriction enzymes EcoRV, EcoRI, and BamHI and hybridized with a fulllength cDNA probe. DNA blot analysis showed two strong bands in each digest under high stringency conditions (Fig. 3). However, two close BamHI sites and one EcoRI site are present in the genomic DNA sequences of both PmCH4Aa and PmCH4Ab. These results suggest that $P m C h 4 A$ may be a single copy gene in the WWP genome.

$P m C h 4 A$ gene expression in healthy seedlings and seedlings infected by $\boldsymbol{C}$. ribicola. To detect $\mathrm{PmCh} 4 \mathrm{~A}$ chitinase, an antibody against the synthesized peptide of an antigenic region in $\mathrm{PmCh} 4 \mathrm{~A}$ was raised and purified by affinity chromatography. The specificity of this antibody was established by western blot analysis. Western blot analysis demonstrated that this antibody specifically detected only one or two bands with the expected size of PmCh4A in crude protein extract from pathogen-infected tissues.

The PmCh4A chitinase protein was not detected by western immunoblot in the total proteins extracted from any organs of healthy seedlings before $C$. ribicola infection (data not shown). However, the PmCh4A protein was found to have accumulated in different parts of both susceptible and SCG resistant seedlings 3 years after fungal infection. Western immunoblot analysis demonstrated that the accumulation pattern of PmCh4A chitinase in needles was similar to that of Cro $\mathrm{r}$ I, a $C$. ribicola protein we used as an indicator for the level of fungal infection in host tissues (15). The highest level of both Cro $\mathrm{r}$ I and $\mathrm{PmCh} 4 \mathrm{~A}$ proteins was detected in current-year needles, with the next highest level in

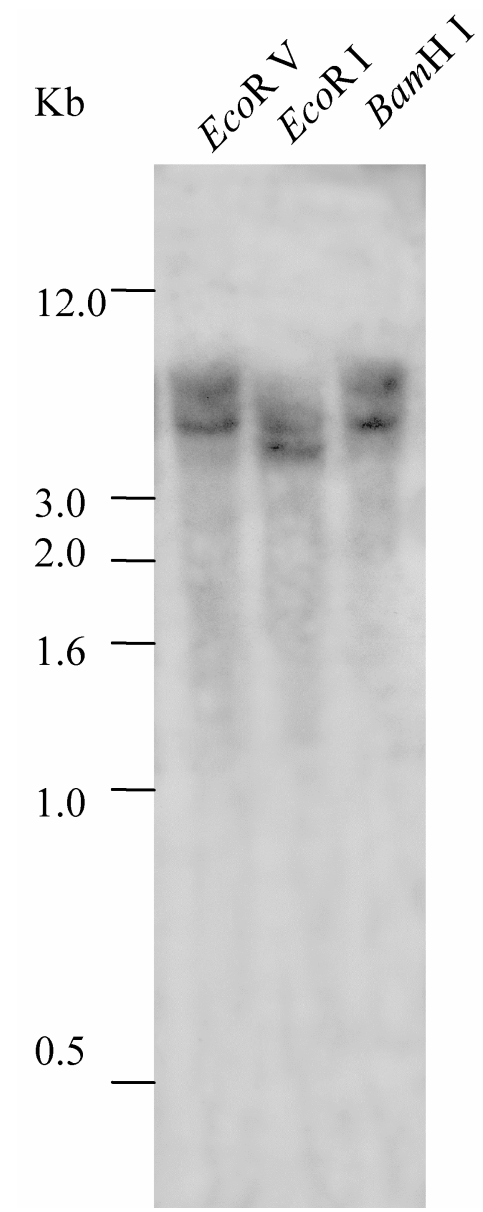

Fig. 3. PmCh4A genomic copy number determined by Southern blot analysis. Western white pine genomic DNA ( $20 \mu \mathrm{g}$ per lane) was digested with restriction enzymes indicated above and separated by electrophoresis on a $0.8 \%$ agarose gel. DNA samples were transferred onto a nylon membrane and hybridized with a DNA probe of $P m C h 4 A$ cDNA. 
1-year-old needles and the lowest level in 2-year-old needles (Fig. $4 \mathrm{~A}$ and D). Fungal Cro $\mathrm{r}$ I protein distribution in twigs of different ages was similar to that in needles of different ages; PmCh4A protein level showed no significant difference among twigs of different ages (Fig. 4B and E).

Stem bark tissues were sampled only from cankered susceptible seedlings and not from SCG seedlings because this would have destroyed seedlings saved for orchard propagation. Accumulation of PmCh4A proteins in bark tissues sampled from canker regions and regions adjacent to cankers on infected stems of susceptible seedlings was analyzed (Fig. 5). A high level of Cro r I was observed in cankers and in the marginal regions with yellow color, adjacent to cankers. Cro $\mathrm{r}$ I was still detectable in the healthy regions away from the canker (Fig. 4C and F). The accumulation pattern of PmCh4A protein was the inverse of that of Cro $\mathrm{r}$ I protein; PmCh4A protein was rarely detected in the canker, but a moderate level of PmCh4A protein was found in the marginal regions and a high level in the healthy regions (Fig. 4C and F).

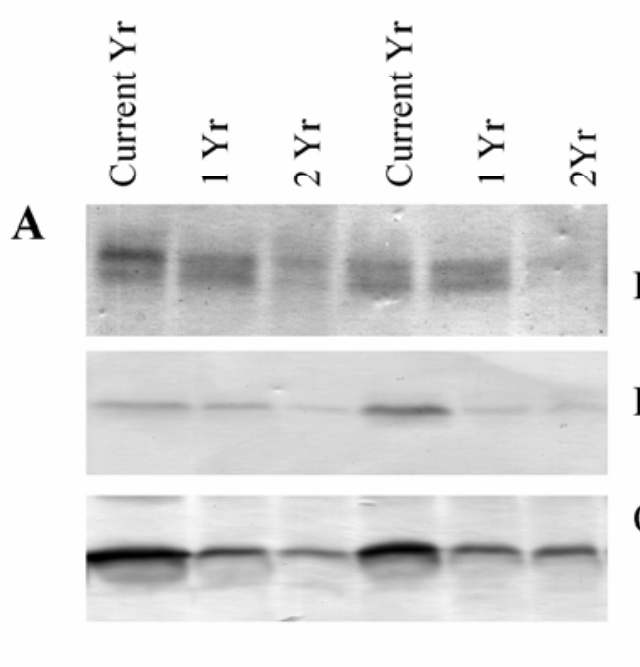

B
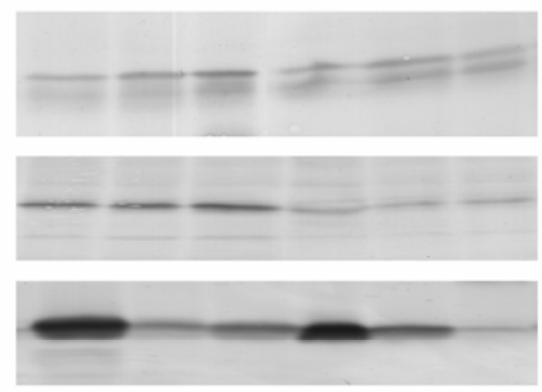

PmCh4A-R

Cro r I-S

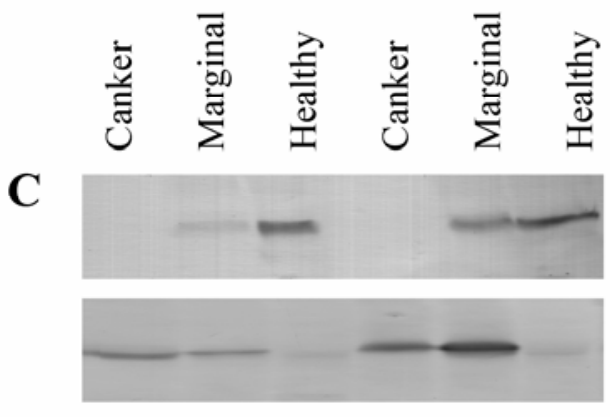

PmCh4A-S

PmCh4A-R

PmCh4A-S

Cro r I-S
PmCh4A-S

Cro r I-S
D

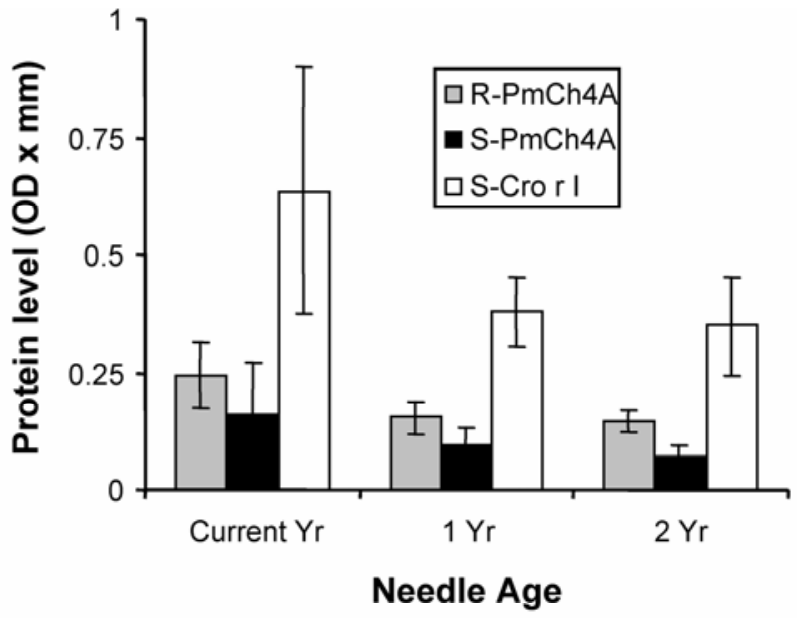

$\mathbf{E}$
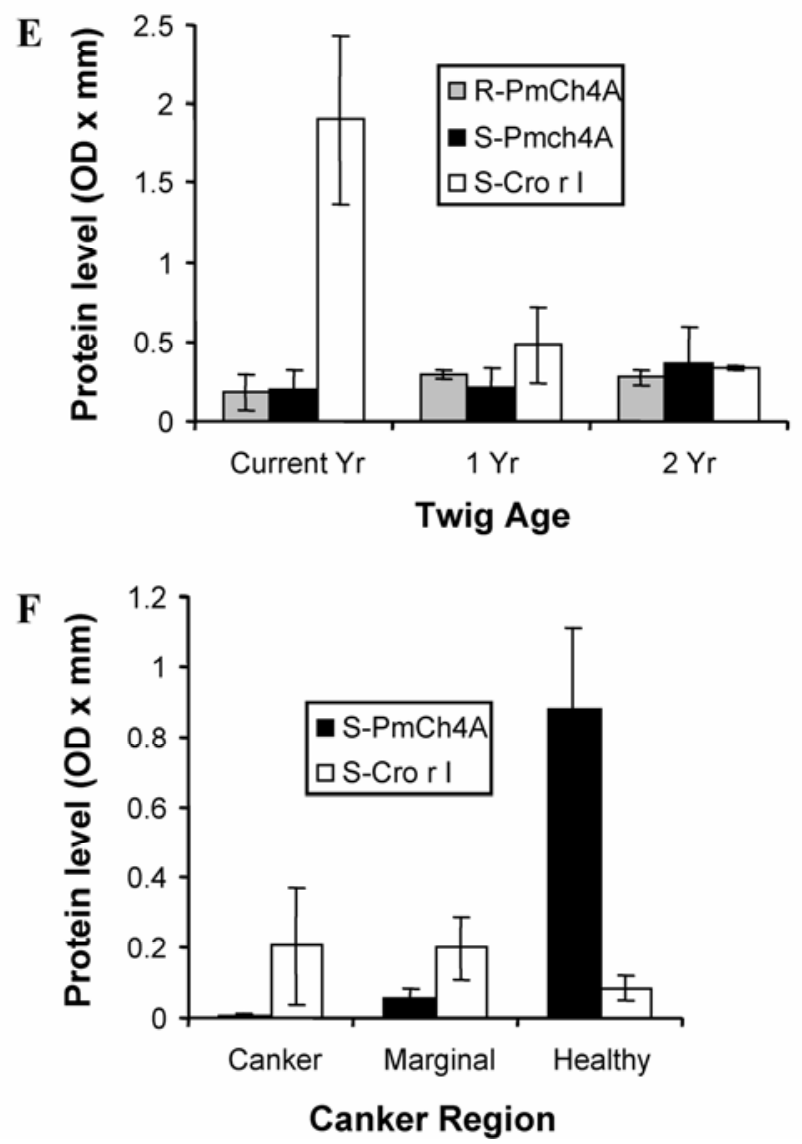

Fig. 4. Accumulation of PmCh4A chitinase in Cronartium ribicola-infected Western white pine organs of susceptible and slow-canker-growth (SCG) resistant seedlings. Western immunoblot analyses were performed to detect PmCh4A chitinase accumulation in different organs 3 years after infection by $C$. ribicola. Total protein samples were extracted from plant tissues. Protein extracts $(50 \mu \mathrm{g}$ per lane) were separated on $12 \%$ sodium dodecyl sulfate-polyacrylamide gel electrophoresis gels and transferred onto PVDF membranes. The protein blots were detected with an antibody against PmCh4A protein or an antibody against the fungal protein Cro $\mathbf{I}$ of $C$. ribicola. $\mathbf{A}$ and $\mathbf{D}$, Protein levels in needles of different ages; $\mathbf{B}$ and $\mathbf{E}$, protein levels in twigs of different ages; and $\mathbf{C}$ and $\mathbf{F}$, protein levels in different regions of canker-lesioned barks of susceptible seedlings. A, B, and C, Western immunoblot analyses show results from only two of nine seedlings. D, E, and F, Bar graphs show quantified protein levels. Western immunoblot signals were quantified using Quantity One Software (Bio-Rad, Mississauga, Canada). Each bar represents the means $( \pm$ SE) of nine individual seedlings. R-PmCh4A, PmCh4A chitinase level in the tissues of SCG resistant (R) seedlings; S-PmCh4A, PmCh4A chitinase level in the tissues of susceptible (S) seedlings; S-Cro r I, Cro r I protein level in the tissues of susceptible (S) seedlings. 
The PmCh4A antibody detected similar chitinase accumulations in the susceptible and SCG resistant seedlings; however, only one chitinase isozyme of $27 \mathrm{kDa}$ was detected in all susceptible seedlings, whereas two chitinase isozymes of 27 and $26 \mathrm{kDa}$ were observed in all SCG resistant seedlings (Fig. 4).

$P m C h 4 A$ expression induced in response to signal chemicals and wounding. To characterize defense-related activation of chitinase synthesis, the responses to signal compound MeJ and OA were investigated. As shown in Figure 6, western immunoblot analysis revealed the time course accumulation of $\mathrm{PmCh} 4 \mathrm{~A}$ protein in needles treated with $\mathrm{MeJ}$ and $\mathrm{OA}$. MeJ at $1 \mu \mathrm{M}$ stimulated the accumulation of chitinase within 2 days of treatment. The enhanced effect of MeJ on chitinase accumulation continued through 4 days after treatment, 4 days being the longest time tested (Fig. 6). Compared with the control (0 days), the treatment with $1 \mu \mathrm{M}$ OA also significantly increased levels of PmCh4A protein in WWP needles (Fig. 6). Wounding also induced PmCh4A chitinase to a barely detectable level 8 days posttreatment (Fig. 6). These results suggest that $\mathrm{PmCh} 4 \mathrm{~A}$ protein accumulation in plant defense is mediated by signal chemicals.

\section{DISCUSSION}

In a candidate gene approach to study conifer defense response against white pine blister rust, we cloned a class IV chitinase gene (PmCh4A) from WWP using a PCR strategy. The differential protein expression of PmCh4A was characterized under $C$. ribicola attack in both susceptible and SCG resistant seedlings by western blot analysis. Class IV chitinase genes have been reported from a few angiosperms, but few have been studied in conifer species, and to our knowledge, this is the first description of a chitinase gene in WWP. Constitutive expression of PmCh4A mRNA was detected in roots, stems, and vegetative shoots (data not shown). In other plant species, class IV chitinase expression was found during embryogenesis $(9,10,35)$, in senescing Brassica napus leaves (17), and in ripening grape berries (38). This suggests that class IV chitinases participate in plant growth and development.

The expression of class IV chitinase not only varies by developmental stage in plant growth but is regulated by biotic and abiotic stresses. Like other PR proteins induced in the conifer defense response (12), the accumulation of PmCh4A protein during C. ribicola infection suggests a role in disease resistance. In the present study, a fungal marker probe (antibody against Cro $\mathrm{r}$ I protein) was used to indicate the colonization of $C$. ribicola in WWP organs (Fig. 4). In the needles where the initial infection occurred, the induced PmCh4A levels were positively related to the fungal
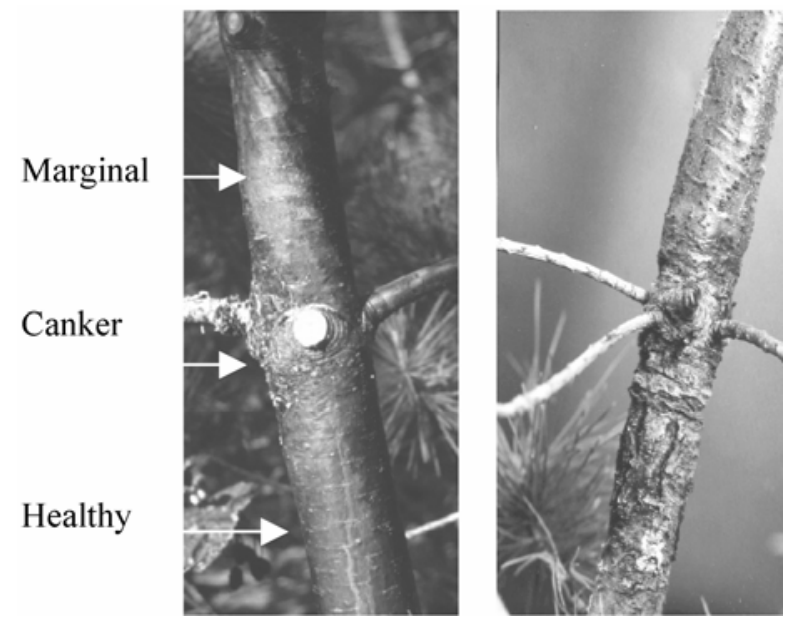

Fig. 5. The morphologies of a canker developed on the bark of a susceptible seedling (left) and of one phenotype of slow-canker-growth resistance to Cronartium ribicola in western white pine (right). infection levels (Fig. 4A). After infection, the pathogen grew and spread from needles to twigs and developed into cankers on the stems. The apparent inhibition of PmCh4A in cankers or canker margins (Fig. 4C) suggests the pathogen may have some mechanism to overcome the host defense response in susceptible seedlings. The isozyme pattern of class IV chitinases in SCG resistant seedlings after fungal challenge differed from that found in susceptible seedlings (Fig. 4). This result suggests that PmCh4A, among a set of inducible PR proteins triggered by the hostpathogen interaction (25), may play a role in genetic resistance to C. ribicola infection in WWP.

Similar to other PR3 genes (16,32), PmCh4A transcript was strongly induced in needles in response to mechanical wounding (data not shown). The wound-inducible mRNA expression of WWP PR3 (PmCh4A) and PR10 genes reached a high level 1 day posttreatment, as did chitinase mRNAs observed in other species (16). The speed and maintenance of the response seems to depend on the types of organs wounded, treatment procedures, and which chitinase is examined (16). In many cases, wounding results in the accumulation of both chitinase protein and mRNA (16). PmCh4A transcript was not detectable in the needles, but increased to high levels from 1 to 8 days postwounding treatment, the longest interval tested (data not shown). During the same time course, woundinduced protein accumulation of PmCh4A was very slow and weak (Fig. 6), which was also the case for tobacco class II chitinases PR-P and PR-Q (16).

C. ribicola infects WWP, causing blisters, and these wound sites provide pathways by which other pathogens can infect the plant. Defense-related proteins, such as chitinases, PR10 proteins $(11,26)$, and thaumatin-like proteins $(36)$, are induced in WWP
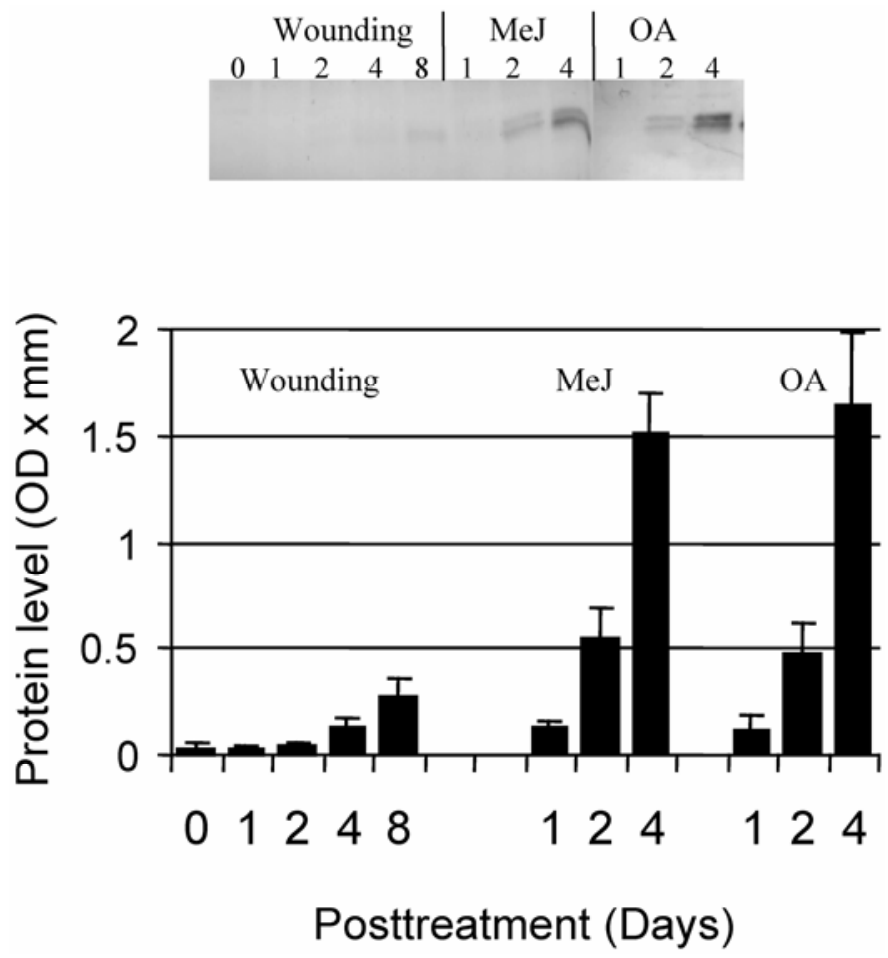

Fig. 6. Time course expression of $\mathrm{PmCh} 4 \mathrm{~A}$ chitinase in slow-canker-growth resistant western white pine in response to wounding, methyl jasmonate $(\mathrm{MeJ})$, and okadaic acid (OA) treatments. Needles were harvested for protein extraction at 0 (day; control), 1, 2, 4, and 8 days after wounding, $1 \mu \mathrm{M} \mathrm{MeJ}$ treatment, or $1 \mu \mathrm{M}$ OA treatment, respectively. Top panel shows western immunoblot analysis; bottom panel shows quantified PmCh4A protein levels. Protein extracts ( $50 \mu \mathrm{g}$ per lane) were separated by electrophoresis on sodium dodecyl sulfate-polyacrylamide gels, blotted to PVDF membranes, and detected using a PmCh4A antibody. Western immunoblot signals were quantified using Quantity One Software (Bio-Rad, Mississauga, Canada). Each bar represents the means $( \pm \mathrm{SE})$ of three independent experiments. 
around wound sites. These PR proteins may create a molecular barrier that synergistically prevents pathogen invasion in WWP. Class IV chitinase genes have been found to be involved in plant defense response after pathogen attack in angiosperm species, including A. thaliana (8), Beta vulgaris (34), Brassica napus (37), Medicago truncatula (40), and Phaseolus vulgaris $(23,29)$. Class I chitinases in the PR3 family were shown to inhibit the growth of many fungi in vitro $(1,16,30,32,42)$. However, the antifungal activity of PmCh4A against $C$. ribicola has yet to be investigated.

The plant growth regulator JA and its methyl ester, MeJ, are naturally present in plant tissues and are involved in both regulation of plant development and response to environmental stresses such as wounding and pathogen attack. As a signaling chemical, MeJ mediates the inducible expression of PR genes in the plant defense response (5). OA is a membrane-permeable inhibitor of serine and threonine phosphatase type 1 and type 2A. Protein phosphorylation and dephosphorylation play key roles in the regulation of gene expression through a complex network of signal-transduction pathways initiated by environmental factors (19). MeJ and pathogen challenge have induced transcripts of both class I and IV chitinases in Pinus elliottii (7). In this study, PmCh4A expression was induced by biotic and abiotic stresses, suggesting that it may play an important role in the plant defense response. However, there is no direct evidence regarding signaling pathways or components that regulate class IV chitinase expression in WWP. Our results revealed that MeJ, OA, and C. ribicola infection resulted in the accumulation of PmCh4A chitinase (Figs. 4 and 6) and PR10 proteins (26). The increase in PR3 and PR10 protein levels induced by OA suggests that hyper-phosphorylation of one or more target proteins may be involved in the signal-transduction pathway of the defense response in WWP.

During the last 5 years, seedlings carrying the $\mathrm{Cr} 2$ resistant gene were repeatedly inoculated with $C$. ribicola isolates from British Columbia, and this resistance gene protects against these isolates (12). In a subsequent study, the dominant resistance gene $\mathrm{Cr} 2$ was crossed into SCG to establish $\mathrm{Cr} 2 \times \mathrm{SCG}$ seed orchards in British Columbia. Such hybrids will be used as pollen sources in tree breeding. Offspring carrying $\mathrm{Cr} 2$ can readily be identified from inoculation studies, but SCG occurs in the stem and is masked by the $\mathrm{Cr} 2$ defense. Because of this masking, a marker for SCG is needed to identify its presence in $\mathrm{Cr} 2$ trees. One $26-\mathrm{kDa}$ PmCh4A isozyme accumulated exclusively in SCG resistant seedlings following fungal challenge by western blot analysis (Fig. 4). The isozyme's application as a potential molecular tool for marker-assisted selection in WWP breeding at early stages of disease infection is being investigated within a larger population. This exclusivity to SCG resistant seedlings suggests that there may be a difference in chitinase gene regulation, posttranslational modification, or gene organization between susceptible and SCG trees. Identification of a DNA marker for SCG resistance selection will shorten the time required to select SCG seedlings in a breeding program from 6 or 7 years to a few months.

\section{ACKNOWLEDGMENTS}

This research was funded by the Canadian Forest Service, the Genomics Research Initiative and Forest Innovation Investment awarded to A. K. M. Ekramoddoullah. We thank I. Leal, R. Sturrock, H. Williams, and M. Keiran for critical reading of and thoughtful comments on the manuscript, and M. Chong and S. Lane for technical assistance.

\section{LITERATURE CITIED}

1. Arlorio, M., Ludwig, A., Boller, T., and Bonfante, P. 1992. Inhibition of fungal growth by plant chitinases and $\beta$-1,3-glucanases-A morphological study. Protoplasma 171:34-43.

2. Bairoch, A. 1992. PROSITE: A dictionary of sites and patterns in proteins. Nucleic Acids Res. 20(Suppl.):2013-2018.
3. Bishop, J. G., Dean, A. M., and Mitchell-Olds, T. 2000. Rapid evolution in plant chitinases: Molecular targets of selection in plant-pathogen coevolution. Proc. Natl. Acad. Sci. USA 97:5322-5327.

4. Broglie, K., Chet, I., Holliday, M., Cressman, R., Biddle, P., Knowlton, S., Mauvais, C. J., and Broglie, R. 1991. Transgenic plants with enhanced resistance to the fungal pathogen Rhizoctonia solani. Science 254:11941197.

5. Creelman, R. A., and Mullet, J. E. 1995. Jasmonic acid distribution and action in plants: Regulation during development and response to biotic and abiotic stress. Proc. Natl. Acad. Sci. USA 92:4114-4119.

6. Davidson, J. J., and Ekramoddoullah, A. K. M. 1997. Analysis of bark protein in blister rust-resistant and susceptible western white pine (Pinus monticola). Tree Physiol. 17:663-669.

7. Davis, J. M., Wu, H., Cooke, J. E., Reed, J. M., Luce, K. S., and Michler, C. H. 2002. Pathogen challenge, salicylic acid, and jasmonic acid regulate expression of chitinase gene homologs in pine. Mol. Plant-Microbe Interact. 15:380-387.

8. De Gerhardt, L. B., Sachetto-Martins, G., Contarini, M. G., Sandroni, M., de Ferreira, P. R., de Lima, V. M., Cordeiro, M. C., de Oliveira, D. E., and Margis-Pinheiro, M. 1997. Arabidopsis thaliana class IV chitinase is early induced during the interaction with Xanthomonas campestris. FEBS Lett. 419:69-75.

9. De Jong, A. J., Cordewener, J., Lo Schiavo, F., Terzi, M., Vandekerckhove, J., Van Kammen, A., and De Vries, S. C. 1992. A carrot somatic embryo mutant is rescued by chitinase. Plant Cell 4:425-433.

10. Dong, J. Z., and Dunstan, D. I. 1997. Endochitinase and beta-1,3glucanase genes are developmentally regulated during somatic embryogenesis in Picea glauca. Planta 201:189-194.

11. Ekramoddoullah, A. K. M., Davidson, J. J., and Taylor, D. 1998. A protein associated with frost hardiness of western white pine is up-regulated by infection in the white pine blister rust pathosystem. Can. J. For. Res. 28:412-417.

12. Ekramoddoullah, A. K. M., and Hunt, R. S. 2002. Challenges and opportunities in studies of host-pathogen interactions in forest tree species. Can. J. Plant Pathol. 24:408-415.

13. Ekramoddoullah, A. K. M., Liu, J.-J., and Zamani, A. 2004. Identification and characterization of a putative anti-fungal $10.6 \mathrm{kDa}$ protein in the white pine blister rust pathosystem. Can. J. Plant Pathol. 26:122.

14. Ekramoddoullah, A. K. M., and Tan, Y. 1998. Differential accumulation of proteins in resistant and susceptible sugar pine (Pinus lambertiana) seedlings inoculated with white pine blister rust fungus (Cronartium ribicola). Can. J. Plant Pathol. 20:308-318.

15. Ekramoddoullah, A. K. M., Tan, Y., Yu, X., Taylor, D. W., and Misra, S. 1999. Identification of a protein secreted by the blister rust fungus Cronartium ribicola in infected white pines and its cDNA cloning and characterization. Can. J. Bot. 77:800-808.

16. Graham, L. S., and Sticklen, M. B. 1994. Plant chitinases. Can. J. Bot. 72:1057-1083

17. Hanfrey, C., Fife, M., and Buchanan-Wollaston, V. 1996. Leaf senescence in Brassica napus: Expression of genes encoding pathogenesis-related proteins. Plant Mol. Biol. 30:597-609.

18. Hunt, R. S. 1997. Relative value of slow canker growth and bark reaction as resistance responses to white pine blister rust. Can. J. Plant Pathol. 19:352-357.

19. Hunter, T., and Karin, M. 1992. The regulation of transcription by phosphorylation. Cell 70:375-387.

20. Jach, G., Gornhardt, B., Mundy, J., Logemann, J., Pinsdorf, E., Leah, R., Schell, J., and Maas, C. 1995. Enhanced quantitative resistance against fungal disease by combinational expression of different barley antifungal proteins in transgenic tobacco. Plant J. 8:97-109.

21. Kinloch, B. B., Sniezko, R. A., Barnes, G. D., and Greathouse, T. E. 1999. A major gene for resistance to white pine blister rust in western white pine from the western Cascade Range. Phytopathology 89:861-867.

22. Kuhner, M. K., and Felsenstein, J. 1994. A simulation comparison of phylogeny algorithms under equal and unequal evolutionary rates. Mol. Biol. Evol. 11:459-468.

23. Lange, J., Mohr, U., Wiemken, A., Boller, T., and Vogeli-Lange, R. 1996. Proteolytic processing of class IV chitinase in the compatible interaction of bean roots with Fusarium solani. Plant Physiol. 111:1135-1144.

24. Liu, J.-J., and Ekramoddoullah, A. K. M. 2003. Root-specific expression of a western white pine PR10 gene is mediated by different promoter regions in transgenic tobacco. Plant Mol. Biol. 52:103-120.

25. Liu, J.-J., and Ekramoddoullah, A. K. M. 2003. Isolation, genetic variation and expression of TIR-NBS-LRR resistance gene analogs from western white pine (Pinus monticola Dougl. ex. D. Don.). Mol. Genet. Genom. 270:432-441.

26. Liu, J.-J., Ekramoddoullah, A. K. M., and Yu, X. 2003. Differential expression of multiple PR10 proteins in western white pine following wounding, fungal infection and cold-hardening. Physiol. Plant 119: 544-553. 
27. Majeau, N., Trudel, J., and Asselin, A. 1990. Diversity of cucumber chitinase isoforms and characterization of one seed basic chitinase with lysozyme activity. Plant Sci. 68:9-16.

28. Maloy, O. C. 1997. White pine blister rust control in North America: A case history. Annu. Rev. Phytopathol. 35:87-109.

29. Margis-Pinheiro, M., Martin, C., Didierjean, L., and Burkard, G. 1993. Differential expression of bean chitinase genes by virus infection, chemical treatment and UV irradiation. Plant Mol. Biol. 22:659-668.

30. Mauch, F., Mauch-Mani, B., and Boller, T. 1988. Antifungal hydrolases in pea tissue. II Inhibition of the fungal growth by combinations of chitinase and $\beta$-1,3-glucanase. Plant Physiol. 88:936-942.

31. Melchers, L. S., Apotheker-de Groot, M., van der Knaap, J. A., Ponstein, A. S., Sela-Buurlage, M. S., Bol, J. F., Cornelissen, B. J. C., van den Elzen, P. J. M., and Linthorst, H. J. M. 1994. A new class of tobacco chitinases homologous to bacterial exo-chitinase displays antifungal activity. Plant J. 5:469-480.

32. Neuhaus, J. M. 1999. Plant chitinases (PR3, PR4, PR8, PR11). Pages 77105 in: Pathogenesis-Related Proteins in Plants. S. K. Datta and S. Muthukrishnan, eds. CRC Press, New York.

33. Neuhaus, J. M., Ahl-Goy, P., Hinz, U., Flores, S., and Meins, F., Jr. 1991. High-level expression of a tobacco chitinase gene in Nicotiana sylvestris. Susceptibility of transgenic plants to Cercospora nicotianae infection. Plant Mol. Biol. 16:141-151.

34. Nielsen, K. K., Bojsen, K., Roepstorff, P., and Mikkelsen, J. D. 1994. A hydroxyproline-containing class IV chitinase of sugar beet is glycosylated with xylose. Plant Mol. Biol. 25:241-257.

35. Passarinho, P. A., Hengel, A. J. V., Fransz, P. F., and De Vries, S. C. 2001. Expression pattern of the Arabidopsis thaliana AtEP3/AtchitIV endochitinase gene. Planta 212:556-567.

36. Piggott, N., Ekramoddoullah, A. K. M., Liu, J.-J., and Yu, X. 2004. Gene cloning and expression of a thaumatin-like protein of western white pine (Pinus monticola D. Don). Physiol. Mol. Plant Pathol. 64:1-8.

37. Rasmussen, U., Bojsen, K., and Collinge, D. B. 1992. Cloning and characterization of a pathogen-induced chitinase in Brassica napus. Plant Mol. Biol. 20:277-287.

38. Robinson, S. P., Jacobs, A. K., and Dry, I. B. 1997. A class IV chitinase is highly expressed in grape berries during ripening. Plant Physiol. 114:771-778.
39. Roby, D., Broglie, K., Cressman, R., Biddle, P., Chet, I. L., and Broglie, R. 1990. Activation of a bean chitinase promoter in transgenic tobacco plants by phytopathogenic fungi. Plant Cell 2:999-1007.

40. Salzer, P., Bonanomi, A., Beyer, K., Vogeli-Lange, R., Aeschbacher, R. A., Lange, J., Wiemken, A., Kim, D., Cook, D. R., and Boller, T. 2000. Differential expression of eight chitinase genes in Medicago truncatula roots during mycorrhiza formation, nodulation, and pathogen infection. Mol. Plant-Microbe Interact. 13:763-777.

41. Samac, D. A., and Shah, D. M. 1994. Effect of chitinase antisense RNA expression on disease susceptibility of Arabidopsis plants. Plant Mol. Biol. 25:587-596.

42. Schlumbaum, A., Mauch, F., Vögeli, U., and Boller, T. 1986. Plant chitinases are potent inhibitors of fungal growth. Nature 324:356-367.

43. van Loon, L. C., and van Strien, E. A. 1999. The families of pathogenesisrelated proteins, their activities, and comparative analysis of PR-1 type proteins. Physiol. Mol. Plant Pathol. 55:85-97.

44. Verburg, J. G., Rangwala, S. H., Samac, D. A., Luckow, V. A., and Huynh, Q. K. 1993. Examination of the role of tyrosine-174 in the catalytic mechanism of the Arabidopsis thaliana chitinase: Comparison of variant chitinases generated by site-directed mutagenesis and expressed in insect cells using baculovirus vectors. Arch. Biochem. Biophys. 300:223230.

45. Vierheilig, H., Alt, M., Neuhaus, J. M., Boller, T., and Wiemken, A. 1993. Colonization of transgenic Nicotiana sylvestris plants, expressing different forms of Nicotiana tabacum chitinase, by the root pathogen Rhizoctonia solani and by the mycorrhizal symbiont Glomus mosseae. Mol. Plant-Microbe Interact. 6:261-264.

46. Von Heijne, G. 1983. Pattern of amino acids near signal-sequence cleavage sites. Eur. J. Biochem. 133:17-21.

47. Wubben, J. P., Joosten, M. H. A. J., van Kan, J. A. L., and de Wit, P. J. G. M. 1992. Subcellular localization of plant chitinases and 1,3-betaglucanases in Cladosporium fulvum (syn. Fulvia fulva) infected tomato leaves. Physiol. Mol. Plant Pathol. 41:23-32.

48. Zhu, Y., Maher, E. A., Masoud, S., Dixon, R. A., and Lamb, C. J. 1994. Enhanced protection against fungal attack by constitutive co-expression of chitinase and glucanase genes in transgenic tobacco. Bio/technology 12:807-812. 